\title{
PHYSICOCHEMICAL PROPERTIES AND NUTRITION OF MORINGA OLEIFERA LAM. LEAF EXTRACT: A PRELIMINARY STUDY ON PREPARATION PHYTOSOMES AS HERBAL SUPPLEMENT FOR CHILDREN
}

\author{
MUTIA SARI WARDANA ${ }^{1}$, MAHDI JUFRI ${ }^{2 *}$, ABDUL MUN'IM ${ }^{3}$
}

1Graduate of Pharmaceutical Sciences, Faculty of Pharmacy, Universitas Indonesia, 2Department of Pharmaceutical Technology and Drug Development, Faculty of Pharmacy, Universitas Indonesia, ${ }^{3}$ Department of Pharmacognosy and Phytochemistry, Faculty of Pharmacy, Universitas Indonesia, Depok, 16424, Indonesia Email: mahdi.jufri@farmasi.ui.ac.id

Received: 29 Oct 2021, Revised and Accepted: 30 Nov 2021

\section{ABSTRACT}

Objective: The study aimed to evaluate the physicochemical properties and nutrition of Moringa leaf extract. In addition, the preliminary study for the preparation of Moringa leaf extract-loaded phytosomes for a supplement.

Methods: Extraction of Moringa leaf made using microwave-assisted extraction, followed by evaluation of proximate analysis (water, total ash, acidinsoluble of ash contents, and residual n-hexane), phytochemical screening, and nutrition such as crude protein, amino acids, and minerals (iron, zinc, and calcium). The phytosomes were prepared by the anti-solvent precipitation method and assessed for the morphology, particle size, zeta potential, polydispersity index (PDI), entrapment efficiency (EE), and Fourier-transform infrared spectra.

Results: The nutrition contents of crude protein, iron, zinc, and calcium were $19.61 \pm 0.07 \%, 3.47 \pm 0.00 \mathrm{mg} / 100 \mathrm{~g}, 5.46 \pm 0.05 \mathrm{mg} / 100 \mathrm{~g}$, and $747.40 \pm 4.89 \mathrm{mg} / 100 \mathrm{~g}$, respectively. The amino acids with the highest concentrations were glutamic acid, phenylalanine, aspartic acid, alanine, and arginine in the extract. The best preparation using sonication $10 \mathrm{~min}$ by morphology was a spherical included particle size, PDI, zeta potential, and EE of arginine was $87.16 \pm 1.73 \mathrm{~nm}, 0.22 \pm 0.04,-23.07 \pm 0.76 \mathrm{mV}$, and $108.94 \pm 0.52 \%$, respectively.

Conclusion: These preliminary results provide evidence of the nutritional benefit of Moringa leaf extract-loaded phytosomes as a promising supplement to prevent stunting in children.

Keywords: Moringa oleifera, Stunting, Supplement, Phytosome, Amino acid

(C) 2022 The Authors. Published by Innovare Academic Sciences Pvt Ltd. This is an open-access article under the CC BY license (https://creativecommons.org/licenses/by/4.0/] DOI: https://dx.doi.org/10.22159/ijap.2022v14i1.43477. Journal homepage: https://innovareacademics.in/journals/index.php/ijap

\section{INTRODUCTION}

Stunting refers to $\geq-2$ SD Z-score of height for age below the median child growth standard established by the World Health Organization. Stunting affects approximately 144 million children worldwide, commonly $54.3 \%$ of cases occurring in Asia [1]. The incidence of stunting in Indonesia was $30.8 \%$ in 2018 [2]. Stunted children of age $<5$ y also experience delays in the development of fine motor skills $(2.86 \%)$, gross motor skills (1.90\%), and social independence $(2.10 \%)$ incidences, which are slightly below the respective global estimated rate of $3 \%$ childhood developmental delays [3]. Good nutrition in complementary food for the first $1000 \mathrm{~d}$ of life is considered critical for the physical growth of children for supporting brain development as maturation of myelination to reduce cognitive deficits in children [4, 5]. Essential amino acids (i.e., arginine, glutamine, leucine, lysine, isoleucine, glycine, serine, and valine) correlated to the linear growth of children [6]. The comparison of stunting children had serum concentrations of arginine, glutamate, serine, glycine, glutamine, and asparagine which were significantly lower than non-stunting children [7].

Moringa oleifera Lam. leaf contains various nutrition such as mineral, vitamin, and vegetable protein has a function to increase enzyme activities has a role in protein production as a ligand for DNA sequence promoter for transcription of DNA in development growth children [5]. Suppressing stunting by supplementation from Moringa leaf powder mixed in porridge by enhancing the nutritional and phytochemical, by increasing approximately $11 \%$ protein, $45 \%$ iron, $40 \%$ phenolics, $139 \%$ flavonoids, and $10 \%$ antioxidant activity [8]. Daily supplementation of 5-10 g of Moringa leaf powdered leaf could increase the appetite of children aged $<5 \mathrm{y}$ and the body weight by $0.53 \mathrm{~kg}$ [9]. Moringa leaf extract contains $9.88 \%$ bioaccessible iron, $70.1 \%$ insoluble protein, $3.5 \%$ glutelin, $2.2 \%$ prolamin, and $0.3 \%$ globulin $[10,11]$. Previous studies have reported the biochemical substances of Moringa leaf powder to have low absorption of amino acids because of its anti-nutrient substances (i.e., phytic acid, tannins, and saponins). The fibers and protease inhibitors have favorable effects on digestion [11]. The side effects consumed supplementation of Moringa leaf powder $20 \mathrm{~g}$ daily were reported causing nausea and for safety used consumption $70 \mathrm{~g} /$ day as maximum to avoid the toxicity of harmful elements and prolong consumption causing cumulative toxicity $[12,13]$.

The explore supplementation derived from local biodiversity to improve safety against malnutrition is required. Moringa oleifera plant is beneficial as a supplement for suppressing stunting, but the absorption of amino acids is inadequate owing to polar phytoconstituents and antinutrient substances. Various solutions to overcome this problem included the preparation of phytosomes as promising strategies to increase absorption. Phytosomes are the complexion of extract and phospholipid to transport the outer membrane wall to reach circulation systemic. Thus, phytosomes are more easily absorbed [14]. The study aimed to evaluate the physicochemical properties and nutrition of Moringa leaf extract as a preliminary study to prepare Moringa leaf extract-loaded phytosomes for a supplement.

\section{MATERIALS AND METHODS}

\section{Materials}

Moringa oleifera leaf purchased from CV Herbal Anugrah Alam, Bantul, Yogyakarta, Indonesia, and verified by The Indonesian Institute of Sciences, Bogor Botanical Gardens (West Java, Bogor, Indonesia) with the authentication number B-1579/IPH.3/KS/XII/2020, phospholipid (Lipoid GmbH Ludwigshafen am Rhein, Germany), alpha-aminobutyric acid (AABA), yttrium, dichloromethane, n-hexane (Merck KGaA, Darmstadt, Germany), water for injection (PT. Ikapharmindo Putramas, East Jakarta, Indonesia), in addition to analytical-grade of all reagents and solvents.

\section{Preparation and extraction}

The extract prepared using $3 \mathrm{~kg}$ of Moringa leaf powders were macerated in $5 \mathrm{l}$ of n-hexane for $24 \mathrm{~h}$ at $25^{\circ} \mathrm{C}$ and then filtered. The 
powdered residue was re-macerated nine times until produced clear liquid. Next, the solvent was filtered, and the powder dried in a drying cabinet. Extraction used microwave (Buono-MV 3002, modified; MODENA, Jakarta, Indonesia) for $8 \mathrm{~min}$ and $70 \%$ tool power equivalent of $630 \mathrm{~W}$ to obtain ratio 1:8 (sample:solvent $50 \%$ ethanol), which was subsequently filtered. The filtrate was concentrated using a rotary vacuum evaporator (Buchi LabortechnikAG, Swiss) and dried in a vacuum oven at $40{ }^{\circ} \mathrm{C}$ (Memmert $\mathrm{GmbH}+\mathrm{Co}$. KG, Büchenbach, Germany) to produce a viscous extract [15].

\section{Physicochemical properties}

The extract was determined organoleptically and proximately analysis. Extraction yield by calculation dividing the extract weight obtained by the weight of the powder. The water content was determined using the distillation of the toluene method. The total ash and acid-insoluble ash contents were analyzed using the gravimetrical method. The residual $n$-hexane was analyzed using gas chromatography, which separated the mixture, and the components, then evaporated at $400{ }^{\circ} \mathrm{C}$ using gas as the mobile phase $[16,17]$.

\section{Phytochemical screening}

The phytochemical screening identifies alkaloids, tannins, saponins, flavonoids, triterpenoids, steroids, glycosides, and anthraquinones. The test used special chemical reagents was analyzed by following the standard method $[18,19]$.

\section{Nutrition contents}

\section{Crude protein and amino acids}

The nutrition of crude protein content was determined using the Kjeldahl method [20]. The amino acids profile was analyzed using Ultra-Performance Liquid Chromatography (UPLC). The standard amino acids solution made with $40 \mu \mathrm{l}$ amino acid solution added 40 $\mu \mathrm{l}$ internal AABA and $920 \mu \mathrm{l}$ double-distilled water. Preparation of sample using $1 \mathrm{~g}$ was placed in a vial, hydrolyzed by adding $5 \mathrm{ml}$ hydrochloric acid, and homogenized by vortexing for $5 \mathrm{~min}$. The samples were heated in an oven at $110^{\circ} \mathrm{C}$ for $22 \mathrm{~h}$. afterward, it was diluted in $50 \mathrm{ml}$ double-distilled water, then filtered using a $0.2 \mu \mathrm{m}$ syringe filter. Then, $500 \mu \mathrm{l}$ of the filtrate pipetted mixed with $40 \mu \mathrm{l}$ of AABA and $460 \mu \mathrm{l}$ of double-distilled water. Next, a $10 \mu \mathrm{l}$ aliquot of standard amino acid or the sample was added with $70 \mu \mathrm{l}$ of AccQTag Ultra borate buffer and homogenized by vortexing. Afterward, $20 \mu \mathrm{l}$ of the AccQ-Tag Ultra-reagent was added and homogenized, let stand for $1 \mathrm{~min}$, and then incubated at oven $55^{\circ} \mathrm{C}$ for $10 \mathrm{~min}$. A total of $1 \mu \mathrm{l}$ standard amino acid or the sample was injected into the UPLC column (Waters Corporation, Milford, USA) with a Photo Diode Array (PDA) detector and a C18 column. The mobile gradient phase included 5\% AccQ-Tag ultra-borate buffer (A) and AccQ-Tag ultrareagent (B) at $0.70 \mathrm{ml} / \mathrm{min}$ at temperature $49^{\circ} \mathrm{C}$ [21].

The tryptophan was analyzed using High-Performance Liquid Chromatography (HPLC). The L-tryptophan standard solution used $25 \mathrm{mg}$ standard L-tryptophan mixed with $10 \mathrm{ml}$ double-distilled water and $0.3 \mathrm{ml}$ hydrochloric acid and sonicated for $15 \mathrm{~min}$ then diluted in $25 \mathrm{ml}$ of double-distilled water. Stock solution $1 \mathrm{ml}$ was added with $10 \mathrm{ml}$ of double-distilled water and mixed well. The working standard solutions made using eight concentrations levels were prepared from the stock solution for the calibration curve. A total of $1 \mathrm{~g}$ samples into a vial and added $10 \mathrm{ml}$ sodium hydroxide and vortexed immediately. The sample was hydrolyzed in an oven at $110{ }^{\circ} \mathrm{C}$ for $22 \mathrm{~h}$. Let cool at $25^{\circ} \mathrm{C}$. Hydrolysate added $3 \mathrm{ml}$ citrate buffer solution and adjusted with hydrochloric acid or sodium hydroxide until pH 4.25. The mixture was diluted with $50 \mathrm{ml}$ of double-distilled water and mixed well. Transfer to $2 \mathrm{ml}$ of centrifugal tube and centrifuge at $14000 \mathrm{rpm}$ for $3 \mathrm{~min}$. Supernatant filtered by using a $0.45 \mu \mathrm{m}$ syringe filter into a vial. A total of $15 \mu \mathrm{l}$ of standard or the sample was injected into the HPLC column (Shimadzu Prominence-i LC 2030, Germany) with a PDA and a C18 reversedphase column. The mobile isocratic phase included sodium acetate (A) and methanol (B) at $1.0 \mathrm{ml} / \mathrm{min}$ at $37^{\circ} \mathrm{C}[22]$.

\section{Minerals}

The nutrition of minerals included iron, zinc, and calcium analyzed using Inductively Coupled Plasma Optical Emission Spectroscopy
(ICP-OES). A total of $10 \mathrm{mg} / \mathrm{l}$ of standard solutions were prepared in $100 \mathrm{ml}$ volumetric flasks from the minerals standard stock solutions that contained $1000 \mathrm{mg} / \mathrm{l}$ for each element. Stock solution $1 \mathrm{ml}$ added with $10 \mathrm{ml}$ of double-distilled water, mix well. The working standard solutions made using eight concentrations levels were prepared from the stock solution with double-distilled in concentrated nitric acid for the calibration curve. A total of $1 \mathrm{~g}$ samples was added to $10 \mathrm{ml}$ of concentrated nitric acid in a digesting vessel, then heated in a microwave digestion system at $150^{\circ} \mathrm{C}$ for 10 min and allowed to digest for $15 \mathrm{~min}$. After cooling, the digested solution was moved to a $50 \mathrm{ml}$ flask and mixed with $0.5 \mathrm{ml}$ of internal standard diluted to $100 \mathrm{mg} / \mathrm{l}$ in double-distilled water. The filtered by using a filter paper Whatman no. 42 , the samples were determined using ICP-OES (Agilent 7500 Agilent Technologies, Inc., USA) [21].

\section{Preparation of phytosomes}

The preparation of phytosomes using the anti-solvent precipitation method [23]. The ratio phospholipid and the Moringa leaf extract used $1: 1(\mathrm{w} / \mathrm{w})$. The phospholipid was dissolved in dichloromethane in a beaker by gentle swirling. After the phospholipid dissolved, it was airdried in a fume hood in $2 \mathrm{~h}$ to obtain a thin film, which was then further dried and dissolved in $10 \mathrm{ml}$ of $\mathrm{n}$-hexane by continuously swirling. Afterward, the film air-dried under a fume hood. Moringa leaf extract solution was added in dried film and sonic by using a probe sonicator on an ice bath to keep the temperature to $<8{ }^{\circ} \mathrm{C}$ at an amplitude $(60 \%)$ at 15 -s pulses. Optimization sonication at a different time (i.e., 5, 7, 10, and $15 \mathrm{~min}$ ). The sonicated sample was stored in a bottle at $2-8{ }^{\circ} \mathrm{C}$ until further analysis.

\section{Evaluation of phytosomes}

\section{Morphology}

The morphology of phytosomes was analyzed using a transmission electron microscope (Jeol JEM-1400 Flash Electron, Japan). The sample was dissolved and placed on a copper-coated grid and dried, then added with $1 \%$ phosphotungstic acid solution, and observed under the microscope.

\section{Particle size, PDI, and zeta potential}

The particle size, PDI, and zeta potential were analyzed using a particle size analyzer and zeta sizer (Malvern Instruments, Ltd., Malvern, UK). The analysis using Dynamic Light Scattering (DLS) method range of -200 to $+200 \mathrm{mV}$. The samples were prepared by dilution $(1: 10)$ in demineralized water and measured in disposable cuvettes at a temperature of $25^{\circ} \mathrm{C}$.

\section{Entrapment efficiency}

The entrapment efficiency was determined using the direct method. The phytosomes $1 \mathrm{ml}$ was poured into a $15 \mathrm{ml}$ centrifuge filter tube (Amicon Ultra, Merck, Germany) and ultracentrifuged (Hitachi CP100WX, Japan) at $13.000 \mathrm{rpm}$ in $5 \mathrm{~h}$ at $4{ }^{\circ} \mathrm{C}$. The sediment was collected and analyzed to estimate the amino acid (AA) contents. The amino acids (AA) in the Moringa leaf extract were glutamic acid, arginine, glycine, and serine selected as the biomarkers. The calculation of entrapment efficiency using the following equation:

$$
\text { Entrapment Efficiency (\%) }=\frac{\text { AA concentration measured }}{A A \text { concentration in teoritical }} \times 100 \%
$$

\section{Fourier-transform infrared spectroscopy}

The molecular interactions were analyzed using a Fouriertransformed infrared spectrometer (FTIR) (Nicolet ${ }^{\mathrm{TM}}$ iS50; Thermo Fisher Scientific). Infrared scans of the extract, phospholipid, physical mixture (extract-phospholipid), and phytosomes. Each 40 $\mathrm{mg}$ of samples was mixed with potassium bromide and then dried in an oven at $40{ }^{\circ} \mathrm{C}$ in $3 \mathrm{~d}$ to remove moisture. Determination of infrared scans at a wavelength of $4000-500 \mathrm{~cm}^{-1}$.

\section{RESULTS AND DISCUSSION}

\section{Preparation and extraction}

Preparation of dried Moringa leaf powder macerated in n-hexane to remove the non-polar compounds may interfere identification of the 
active substances and eliminate the odors. The odor comes from volatile components of aldehydes (i.e., 2-hexenal and benzaldehyde) that reduce consumer acceptance [24]. The yield of n-hexane maceration was $89.62 \%$. The extraction used a modified microwave with a double condenser to prevent evaporation solvent and reduced pressure. The previous study reported extraction yield using microwave was $26 \%$ which is lower compared to our result. Microwave-assisted extraction based on electromagnetic radiation at 0.3 to $300 \mathrm{GHz}$ provides extraction efficiency by shorting extraction times due to increasing the analyte solubility in the extraction solvent [25].

\section{Proximate analysis}

Determination of organoleptic evaluation, proximate analysis, and residual $n$-hexane is urgent for safety considerations presented in table 1. All results met the requirement [16]. The water, total ash, and acidinsoluble ash contents are indices to demonstrate the quality and purity of extract. Based on a previous study of water content $1.06 \%$, total ash $12.76 \%$, and acid-insoluble ash $1.69 \%$, our study was higher in water content and low in acid-insoluble ash contents. The low water content prevents contamination by microorganisms. The acid-insoluble ash contents were low in extract, which indicated the small content of the contaminant. Residual of n-hexane did not exceed 290 ppm owing to inherent toxicity [15].

\section{Phytochemical screening}

The phytochemical screening to identify secondary metabolites shows in table 2. Moringa leaf extract contained alkaloids, flavonoids, tannins, saponins, terpenoids, and glycosides. The previous study found similar to saponins, alkaloids, and flavonoids in very much amounts but different in the presence of steroids, terpenoids, and anthraquinones. Several functions of flavonoids include protecting against inflammatory disorders, diarrhea, microbes invasion, and ulcers. The presence of epicatechin, quercetin, and luteolin in flavonoids plays vital roles in diarrhea [26]. Alkaloids have functioned as a muscle relaxant and antispasmodic for relieving intestinal spasms in diarrhea. Moriginine as an alkaloid prove fatal side effect ingestion which has potentially nerve-paralyzing properties when consumed in high doses [27].

Table 1: Physicochemical properties of Moringa oleifera leaf extract

\begin{tabular}{lll}
\hline Parameters (Units) & Result & Requirement \\
\hline Organoleptic evaluation & & Viscous \\
Form & Viscous & Brown \\
Color & Brown & Bitter \\
Taste & Bitter & Distinctive aroma \\
Odor & Distinctive aroma & \\
Proximate analysis & & Not less than 9.2 \\
Extract yield (\%) & $27.23 \pm 1.40$ & Not more than 10 \\
Water content (\%) & $7.33 \pm 1.15$ & Not more than 9.0 \\
Total ash (\%) & $8.36 \pm 0.60$ & Not more than 0.9 \\
Acid-insoluble ash (\%) & $0.26 \pm 0.09$ & Not detected \\
Residual n-hexane (ppm) & Not detected & \\
\hline
\end{tabular}

Values expressed as mean \pm SD $(n=3)$

Table 2: Phytochemical screening of Moringa oleifera leaf extract

\begin{tabular}{ll}
\hline Metabolites & Result \\
\hline Alkaloids & +++ \\
Saponins & +++ \\
Tannins & ++ \\
Flavonoids & +++ \\
Terpenoids & + \\
Steroids & - \\
Anthraquinones & - \\
Glycosides & ++ \\
\hline
\end{tabular}

+++= very much; ++= much; += little; -= none

\section{Nutrition contents}

The UPLC and HPLC method identified in extract and phyosomes of amino acids, the chromatograms can be seen in fig. 1 and fig. 2 . The nutrition contents of Moringa leaf extract $(100 \mathrm{~g})$ as shown in table 3. The essential and non-essential of 18 amino acid profiles such as glutamic acid, phenylalanine, aspartic acid, alanine, arginine, serine, valine, threonine, proline, glycine, leucine, isoleucine, tryptophan, tyrosine, histidine, lysine, cysteine, and methionine. The amino acids of extract such as glutamic acid, phenylalanine, and aspartic acid were present at the highest concentrations also found cysteine and methionine were at the lowest concentrations. These results are similar to a previous study that found the lowest was cysteine and glutamic acid at the highest concentration as acidic amino acid has good potential of an antioxidant [21]. The previous study reported crude protein, iron, zinc, and calcium reported by $9.4 \%, 4 \mathrm{mg}, 0.60 \mathrm{mg}$, and $185 \mathrm{mg}$, respectively found low nutrition comparison with our results, which is a suitable protein source for a supplement. Differences proximate analysis and nutrition contents because of the variety of plants, geographical location, methods of analysis, and growth conditions. Plant protein has a direct impact on soil type presents nitrogen content. Nitrogen has a role in synthesizing amino acids and proteins, storage of protein in all plant parts such as leaf
[28]. Moringa oleifera Lam. plant used to overcome protein and minerals deficiency with small molecules of $\mathrm{Fe}, \mathrm{Zn}$, Ca storage proteins of amino acids histidine and arginine contributed to combating the child stunting in developing countries. The leaf contains crude protein, amino acids, and minerals in higher amounts compared with spinach. The Moringa leaf could be an alternative to vegetarian or poor people unable to consume protein from meat $[27,29]$.

Table 3: Nutrition contents of Moringa oleifera leaf extract

\begin{tabular}{ll}
\hline Nutrition & Result \\
\hline Crude protein $(\%)$ & $19.61 \pm 0.07$ \\
Amino acids (mg/100g) & $2155.75 \pm 4.14$ \\
Glutamic acid & $998.91 \pm 0.95$ \\
Phenylalanine* & $951.11 \pm 4.37$ \\
Aspartic acid & $748.64 \pm 2.11$ \\
Alanine & $729.19 \pm 6.56$ \\
Arginine** & $545.34 \pm 1.25$ \\
Serine & $398.40 \pm 1.10$ \\
Valine* & $395.48 \pm 0.91$ \\
Threonine* & $382.31 \pm 1.65$ \\
Proline** & $348.32 \pm 0.80$ \\
Glycine** & $344.82 \pm 2.15$ \\
Leucine* & $251.44 \pm 0.67$ \\
Isoleucine* & $212.74 \pm 2.05$ \\
Tryptophan* & $195.30 \pm 1.03$ \\
Tyrosine** & $164.46 \pm 1.12$ \\
Histidine* & $102.30 \pm 2.71$ \\
Lysine* & $75.55 \pm 0.10$ \\
Cysteine & $6.67 \pm 0.01$ \\
Methionine* & \\
Minerals (mg/100g) & $3.47 \pm 0.00$ \\
Iron & $5.46 \pm 0.05$ \\
Zinc & $747.40 \pm 4.89$ \\
Calcium &
\end{tabular}

Data represented as mean $\pm \mathrm{SD}(\mathrm{n}=2)$, *Essential amino acids; ${ }^{* *}$ Semi-essential amino acids. 


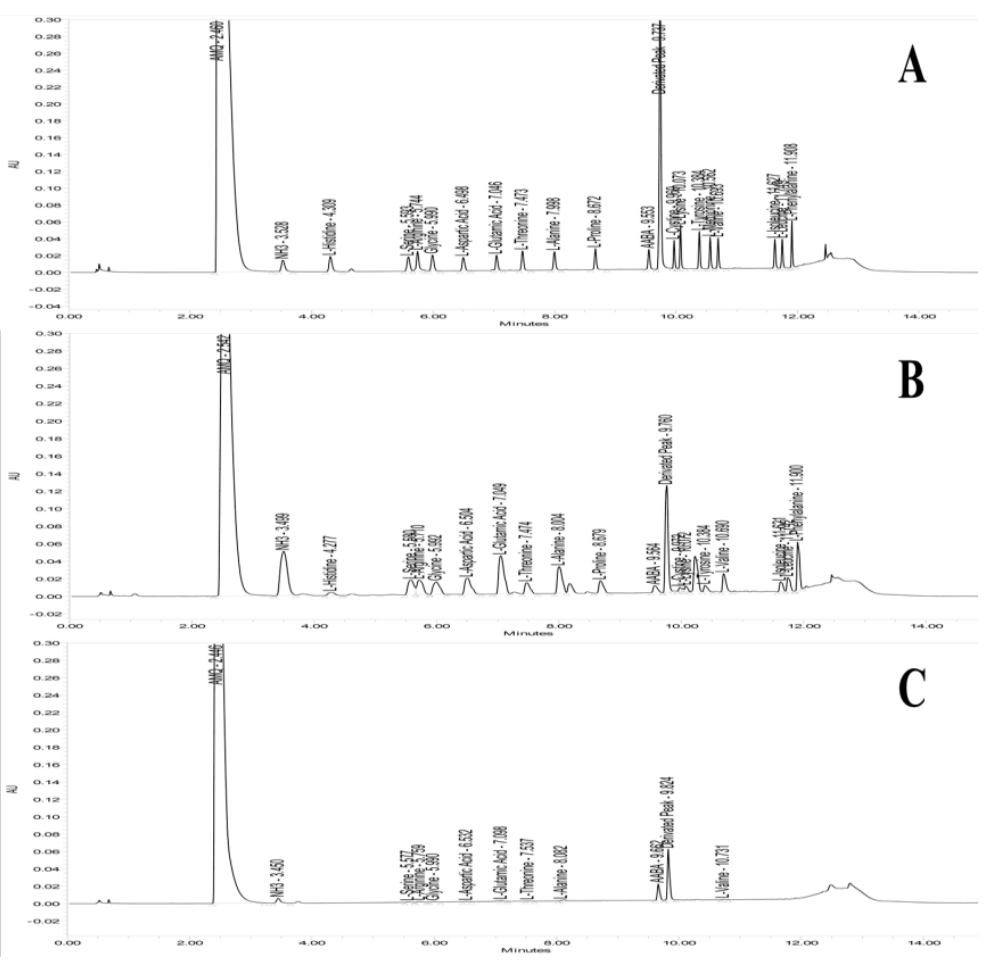

Fig. 1: UPLC chromatograms of amino acids in (A) reference standard (B) Moringa leaf extract and (C) Moringa leaf extract-loaded phytosomes
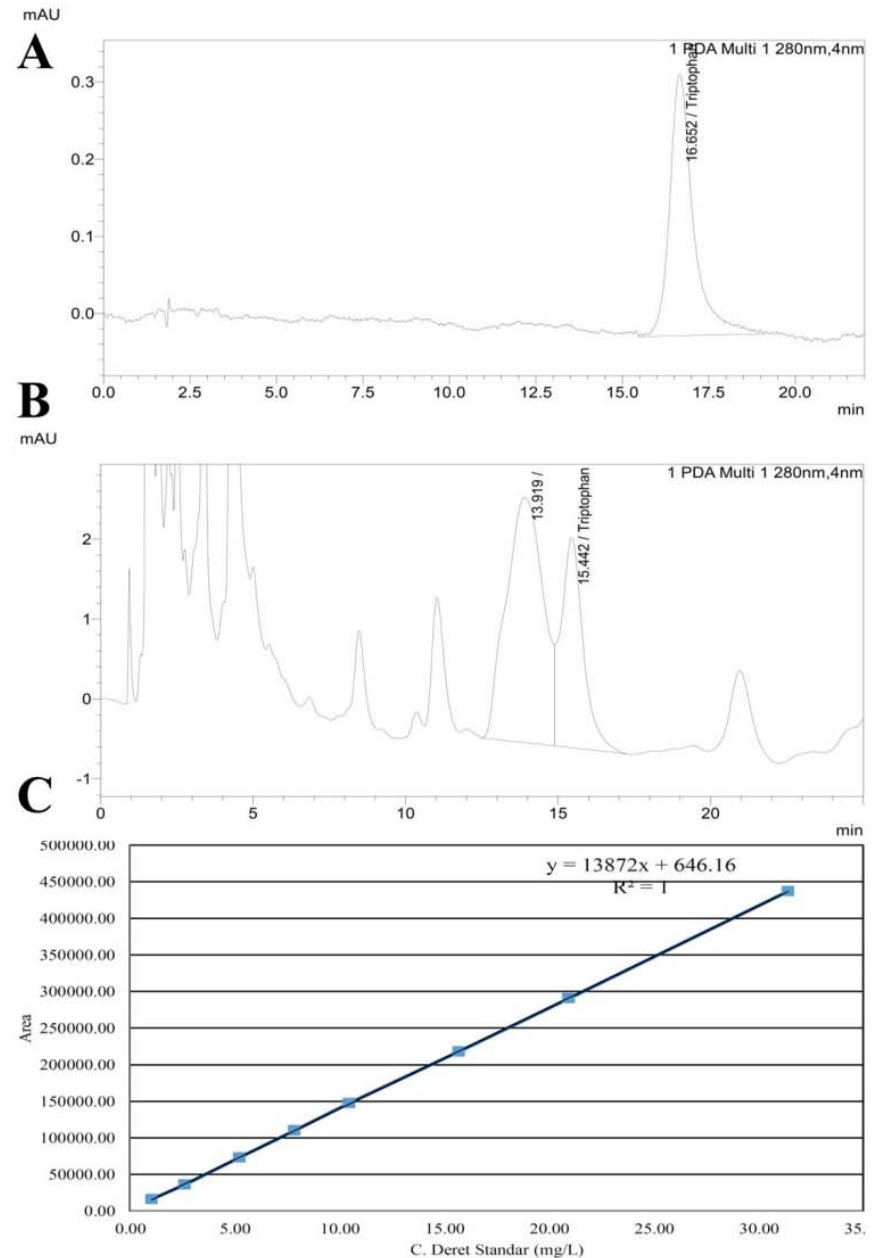

Fig. 2: HPLC chromatograms of tryptophan in (A) reference standard (B) Moringa leaf extract and (C) calibration curve of tryptophan 


\section{Preparation of phytosomes}

The preparation of phytosomes at an optimal weight ratio of phospholipids and the extract was $1: 1$ by an anti-solvent precipitation method using dichloromethane as the medium of reaction an $\mathrm{n}$-hexane used to precipitate phytosomes complex as anti-solvent from the medium solvent [23]. The phytosomes confirmed by organoleptic were light brownish, distinctive odor, and formed sediments easily redispersed. The optimal time of probe sonic was achieved at $10 \mathrm{~min}$ and gave the best characteristics and entrapment efficiency of the phytosomes. The optimized sonic time was shorter than the previous study reported sonication time in 15 min due to different compositions of phytosomes [30].

\section{Evaluation of phytosomes}

\section{Morphology}

The morphology of phytosomes was spherical in shape with the size range of $200 \mathrm{~nm}$ can be seen in fig. 3. This result has similar reported by previous studies confirmed as a single spherical shape and selfclosed structures of the vesicle commonly ranged $50 \mathrm{~nm}$ to $100 \mu \mathrm{m}$. The aggregation between vesicles was not visible and observed in mostly spherical vesicles, relatively uniform sizes, and well-distributed small cells such as micelles seen as a dispersed collection [23, 31].

\section{Particle size and zeta potential}

The best characteristics of particle size, PDI, and zeta potential 87.16 $\mathrm{nm}, 0.22,-23.07 \mathrm{mV}$, respectively, are presented in table 4 and fig. 4 . The previous study reported particle size was larger $198 \mathrm{~nm}$ because of the composition of cholesterol and polysorbate 80 . The nanoparticles at sizes lower than $100 \mathrm{~nm}$ show high direct absorption at the mucus $[30,32]$. The PDI showed $<0.5$ for homogenous particle size. A lower PDI indicates better homogeneity because the large particle size distribution indicates extracts were physically bonded to phospholipid and gave well distributed and homogenous phytosomes suspension [33]. The zeta potential is a measurement of electrostatic attraction or force repulsion between suspension particles to predict stability during storage [34]. The zeta potential was $-23.07 \mathrm{mV}$, which is lower th an the standard around $+25 \mathrm{mV}$ or below $25 \mathrm{mV}$ is essential for colloidal solutions to prevent aggregation and ensure stabilization [35].

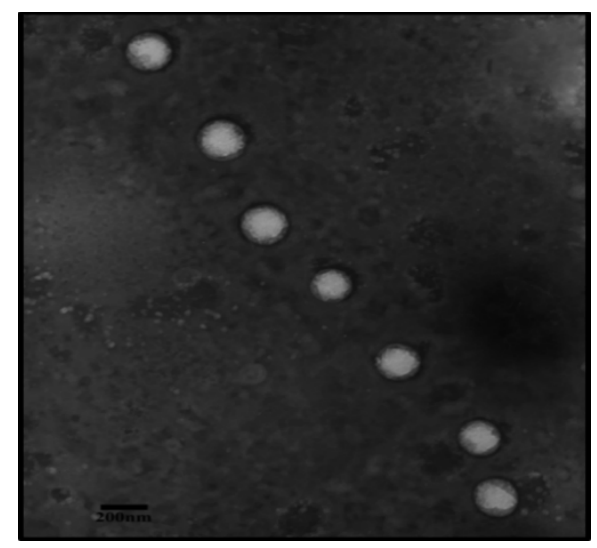

Fig. 3: The morphology of phytosomes with magnification 20.000x

Table 4: The characteristics of phytosomes

\begin{tabular}{llll}
\hline Sonication time & Zeta potential $(\mathbf{m V})$ & Particle size $(\mathbf{n m})$ & Polydispersity index \\
\hline $5 \mathrm{~min}$ & $-21.93 \pm 0,78$ & $95.16 \pm 2,37$ & $0.41 \pm 0,02$ \\
$7 \mathrm{~min}$ & $-21.90 \pm 0,26$ & $80,04 \pm 0,71$ & $0.24 \pm 0,02$ \\
$10 \mathrm{~min}$ & $-23.07 \pm 0,76$ & $87.16 \pm 1,73$ & $0.22 \pm 0,04$ \\
$15 \mathrm{~min}$ & $-21.87 \pm 1,29$ & $197.53 \pm 12,17$ & $0.36 \pm 0,01$ \\
\hline
\end{tabular}

Values are mean $\pm \mathrm{SD}(\mathrm{n}=3)$
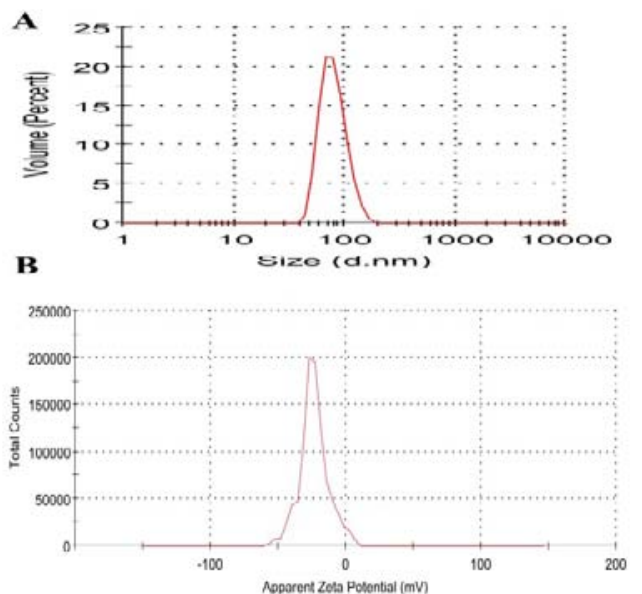

Fig. 4: Chromatogram in (A) particle size distribution and (B) zeta potential

\begin{abstract}
Entrapment efficiency
The entrapment efficiency of amino acids included glutamic acid, arginine, glycine, and serine selected as the biomarkers of infant nutrition and abundance in Moringa leaf extract shown in table 5. Glutamic acid, glycine, and serine correlated with the weightfor-height and the length velocity for infants aged 6-12 mo. Arginine has important rules for infants who are still unable to provide it for their growth requirements $[6,27]$. EE of arginine is $108.94 \%$ which becomes conditionally essential in stunting conditions due to inflammation state needs to balance for increasing linear growth [4]. Nutrition substances in Moringa leaf powder reduce inflammatory processes that occur specifically in stunting. Arginine is a precursor for synthesis molecules of creatine, nitric oxide, ornithine, and proline stimulates the secretion of growth hormone, prolactin, insulin, and glucagon. Arginine plays in the detoxification of ammonia by the urea cycle and has a high turnover in growing infants. The requirement of arginine in infants is very high because used in the high amount of arginine in protein tissues and the multiple utilization pathways for synthesis [5, 36].
\end{abstract}

Table 5: The entrapment efficiency of phytosomes

\begin{tabular}{llll}
\hline Sonication time & Glutamic acid (\%) & Arginine (\%) & Glycine (\%) \\
\hline 5 min & $49.07 \pm 0,66$ & $103.20 \pm 0,51$ & $65.38 \pm 0,18$ \\
7 min & $43.82 \pm 0,54$ & $96.93 \pm 0,20$ & $60,51 \pm 0,55$ \\
$10 \mathrm{~min}$ & $54.84 \pm 1,72$ & $108.94 \pm 0,52$ & $53.58 \pm 0,48$ \\
$15 \mathrm{~min}$ & $42.08 \pm 0,22$ & $102.67 \pm 0,97$ & $77.65 \pm 0,12$ \\
\hline
\end{tabular}

Data represented as mean \pm SD $(n=2)$ 


\section{Fourier-transform infrared spectroscopy}

The molecular interaction identified in FTIR spectra of phytosomes, extract, phospholipids, and physical mixture showed differences in fig. 5 . The spectrum of extracts revealed specific peaks $\mathrm{O}-\mathrm{H}$ stretching vibration of the aromatic ring around $3600 \mathrm{~cm}^{-1}$ and the $\mathrm{N}-\mathrm{H}$ group of amines at $1550 \mathrm{~cm}^{-1}$. The other spectra of phospholipids revealed $\mathrm{C}-\mathrm{H}$ stretching and $\mathrm{C}=\mathrm{O}$ stretching related in the chain of fatty acid peaks at $3000 \mathrm{~cm}^{-1}$ and $1800 \mathrm{~cm}^{-1}$. The physical mixture spectra contained peaks specific to individual components at $3600 \mathrm{~cm}^{-1}, 3000 \mathrm{~cm}^{-1}, 1800$ $\mathrm{cm}^{-1}$, and $1550 \mathrm{~cm}^{-1}$. The phytosomes spectra showed significantly decreased intensity and shifting of- $\mathrm{O}-\mathrm{H}$ peak at $3354 \mathrm{~cm}^{-1}$ and appearance of new peak $\mathrm{N}-\mathrm{H}$ stretching groups of amines at 1600 $\mathrm{cm}^{-1}$. Our result study similar reported decreased intensity and shift of bands- $\mathrm{O}-\mathrm{H}$ peak at range $3200-3600 \mathrm{~cm}^{-1}$ and $\mathrm{N}-\mathrm{O}$ at ranged 1250 $1650 \mathrm{~cm}^{-1}$ as the new peak. These interactions may be due to ionic bonds and or Van der Waals forces. The interactions formed between $-\mathrm{O}-\mathrm{H}$ groups of the extract and the amine phosphate groups of phospholipid [31, 37]. Phytosomes absorbs by endocytosis or paracellular transport from gastrointestinal tissue through enterocytes [38]. Thus, phytosomes can be increased absorption and reduce the required daily dose of supplementation.

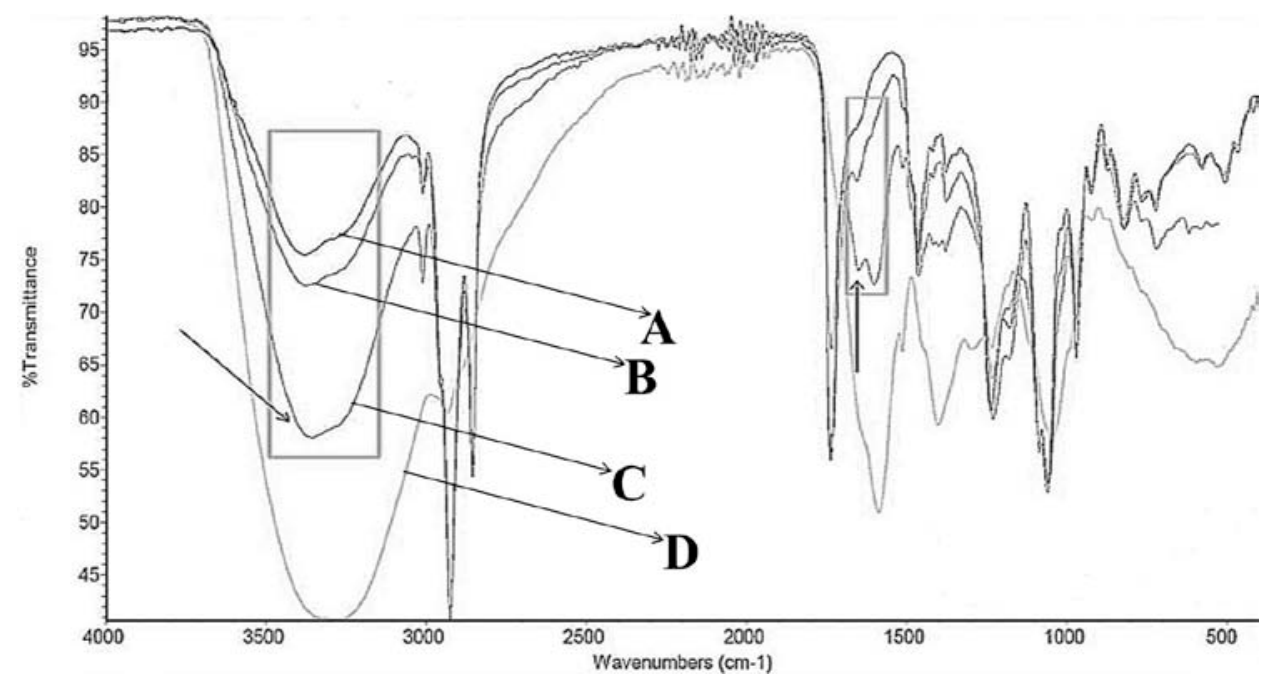

Fig. 5: FTIR spectra of (A) phospholipid (B) physical mixture (C) phytosomes (D) Moringa leaf extract, the boxes, and small arrows showed intensity changes also new peaks in the spectra of Moringa leaf extract-loaded phytosomes

\section{CONCLUSION}

The Moringa oleifera Lam. plant is beneficial as a supplement for suppressing stunting incidence, but the absorption of amino acids is inadequate owing to polar phytoconstituents and anti-nutrient substances. The study aimed to prepare Moringa leaf extract through microwave extraction, followed by an evaluation of physicochemical properties and nutrition of Moringa leaf extract. A preliminary study for the preparation of Moringa leaf extract-loaded phytosomes then characterized the physicochemical properties. The result data presented indicate that Moringa leaf extract is a promising source of protein. Preparation phytosomes used sonic $10 \mathrm{~min}$ had the best properties particle size, zeta potential, polydispersity index, and entrapment efficiency is a promising supplement to prevent stunting in children.

\section{FUNDING}

The authors are thankful for a grant was received from the Base Research Program International Indexed Publication (PUTI), Universitas Indonesia (no ref: ND-420/UN2. RST/PPM.00/2020).

\section{AUTHORS CONTRIBUTIONS}

All the authors have contributed equally.

\section{CONFLICT OF INTERESTS}

The author reports no declarations of interest.

\section{REFERENCES}

1. United Nations Children's Fund, World Health Organization, The World Bank. Levels and trends in child malnutrition: key findings of the. 2020 ed of the joint child malnutrition estimates. Geneva: World Health Organization; 2020.

2. Health Research, Development Agency. National health research basic report 2018. Jakarta: publisher Health Research and development Agency; 2018.
3. Meylia KN, Siswati T, Paramashanti BA, Hati FS. Fine motor, gross motor, and social independence skills among stunted and non-stunted children. Early Child Dev Care. 2020:1-8. doi: 10.1080/03004430.2020.1739028.

4. Furuta C, Murakami H. A novel concept of amino acid supplementation to improve the growth of young malnourished male rats. Ann Nutr Metab. 2018;72(3):231-40. doi: 10.1159/000487603, PMID 29518784.

5. Putra AIYD, Setiawan NBW, Sanjiwani MID, Wahyuniari IAI, Indrayani AW. Nutrigenomic and biomolecular aspect of Moringa oleifera leaf powder as supplementation for stunting children. J Tropical Biodiversity Biotechnology 2021;6(1):60113. doi: 10.22146/jtbb.60113.

6. Ordiz MI, Semba RD, Moaddel R, Rolle-Kampczyk U. Bergen Mv, Herberth G. Serum amino acid concentrations in infants from Malawi are associated with linear growth. Curr Dev Nutr. 2019;3(100):1-4.

7. Semba RD, Shardell M, Sakr Ashour FA, Moaddel R, Trehan I, Maleta KM, Ordiz MI, Kraemer K, Khadeer MA, Ferrucci L, Manary MJ. Child stunting is associated with low circulating essential amino acids. E Biomedicine. 2016;6:246-52. doi: 10.1016/j.ebiom.2016.02.030. PMID 27211567.

8. Ntila SL, Ndhlala AR, Mashela PW, Kolanisi U, Siwela M. Supplementation of a complimentary white maize soft porridge with Moringa oleifera powder as a promising strategy to increase nutritional and phytochemical values: a research note. S Afr J Bot. 2020;129:238-42. doi: 10.1016/j.sajb.2019.07.021. sajb.2019.07.021.

9. Allo J, Sagita S, Woda RR, Lada CO. Effect of moringa oleifera leaf powder supplementation on weight gain of the toddler in the working area of Naibonat health center, Kupang regency. World Nutr J. 2020;4(1):i1.0009. doi: 10.25220/WNJ.V04.i1.0009.

10. Khoja KK, Aslam MF, Sharp PA, Latunde Dada GO. In vitro bioaccessibility and bioavailability of iron from fenugreek, baobab and moringa. Food Chem. 2021;335:127671. doi: /j.foodchem.2020.127671. 
11. Teixeira EMB, Carvalho MRB, Neves VA, Silva MA, Arantes Pereira L. Chemical characteristics and fractionation of proteins from moringa oleifera Lam. leaves. Food Chem. 2014;147:51-4. doi: 10.1016/j.foodchem.2013.09.135, PMID 24206684. foodchem.2013.09.135.

12. Barichella M, Pezzoli G, Faierman SA, Raspini B, Rimoldi M, Cassani E, Bertoli S, Battezzati A, Leone A, Iorio L, Ferri V, Pinelli G, Pusani C, Bolliri C, Cilia R, Caronni S, De Marco P, Cereda E. Nutritional characterization of Zambian Moringa oleifera: acceptability and safety of short-term daily supplementation in a group of malnourished girls. Int J Food Sci Nutr. 2019;70(1):107-15. doi: 10.1080/09637486. 2018.1475550, PMID 29792366.

13. Chhikara N, Kaur A, Mann S, Garg MK, Sofi SA, Panghal A. Bioactive compounds, associated health benefits and safety considerations of moringa oleifera L.: an updated review. Nutr Food Sci. 2021;51(2):255-77. doi: 10.1108/NFS-03-2020-0087.

14. Lu M, Qiu Q, Luo X, Liu X, Sun J, Wang C. Phyto-phospholipid complexes (phytosomes): a novel strategy to improve the bioavailability of active constituents. Asian J Pharm Sci. 2019;14(3):265-74. doi: 10.1016/j.ajps.2018.05.011, PMID 32104457.ajps.2018.05.011.

15. Anggraeni Y, Jufri M, Mun'in A. Instant powder formulation for anti anemia and optimization extraction condition of moringa pterygosperma gaertn leaves using MAE. J Farmasi Indones. 2015;7(3):136-42.

16. Ministry of Health Republic of Indonesia. Indonesian herbal pharmacopeia. 2nd ed. Jakarta: Ministry of Health Republic of Indonesia; 2017.

17. Ministry of Health Republic of Indonesia. Indonesian pharmacopeia. 6th ed. Jakarta: Ministry of Health Republic of Indonesia; 2020.

18. Farnsworth NR. Biological and phytochemical screening of plants. J Pharm Sci. 1966;55(3):225-76. doi: 10.1002/jps.2600550302, PMID 5335471.

19. Harborne JB. Phytochemical methods: a guide to modern techniques of plant analysis. 3rd ed. London, UK: Chapman and Hall, Thomson Sciences; 1998.

20. Association of Official Agricultural Chemists. Official methods of analysis. Washington, DC: Association of Official Agricultural Chemists; 2002.

21. Natsir H, Wahab AW, Budi P, Dali S, Arif AR. Amino acid and mineral composition of moringa oleivera leaves extract and its bioactivity as an antioxidant. J Phys Conf Ser. 2019;1317(1):012030. doi: 10.1088/1742-6596/1317/ $1 / 012030$.

22. Kusharto CM, Rosmiati R, Marta EO, Palupi E. Amino acid composition and protein quality of instant liquid food based on catfish (Clarias gariepinus) and Kelor (Moringa oleifera) flour. IOP Conf Ser.: Earth Environ Sci. 2018;196:012033. doi: 10.1088/1755-1315/196/1/012033.

23. Mazumder A, Dwivedi A, du Preez JL, du Plessis J. In vitro wound healing and cytotoxic effects of the sinigrin-phytosome complex. Int J Pharm. 2016;498(1-2):283-93. doi: 10.1016/j.ijpharm.2015.12.027. PMID 26706438.

24. Dandan K, Shaodan P, Jihua L, Yupo C. Study on the effect of extraction process of Moringa instant tea on its sensory quality. IOP Conf Ser.: Earth Environ Sci. 2018;153(2). doi: 10.1088/1755-1315/153/2/022026, PMID 022026.
25. Rodriguez Perez C, Gilbert Lopez B, Mendiola JA, Quirantes Pine $R$, Segura-Carretero A, Ibanez E. Optimization of microwaveassisted extraction and pressurized liquid extraction of phenolic compounds from Moringa oleifera leaves by multiresponse surface methodology. Electrophoresis. 2016;37(13):1938-46. doi: 10.1002/elps.201600071. PMID 27122439.

26. Adekanmi AA, Adekanmi SA, Adekanmi OS. Qualitative and quantitative phytochemical constituents of Moringa leaf. Int J Eng Inf Syst. 2020;4(5):10-7.

27. Dhakar R, Pooniya B, Gupta M, Maurya S, Bairwa N, Sanwarmal. Moringa: the herbal gold to combat malnutrition. Chron Young Sci. 2011;2(3):119-25. doi: 10.4103/2229-5186.90887.

28. Mehlomakulu NN, Emmambux MN. Nutritional quality of wet and dry processed moringa oleifera lam. Leaves: A review. Food Rev Int. 2020:1-21. doi: 10.1080/87559129.2020.1831527.

29. Fidrianny I, Kanapa I, Singgih M. Phytochemistry and pharmacology of Moringa tree: an overview. Biointerface Res Appl Chem. 2021;11(3):10776-89. doi: 10.33263/ BRIAC113.1077610789.

30. Lim AW, Ng PY, Chieng N, Ng SF. Moringa oleifera leaf extractloaded phytophospholipid complex for potential application as wound dressing. J Drug Deliv Sci Technol. 2019;54:1-9. doi: 10.1016/j.jddst.2019.101329, PMID 101329.

31. Surini S, Mubarak H, Ramadon D. Cosmetic serum-containing grape (Vitis vinifera L.) seed extract phytosome: formulation and in vitro penetration study. J Young Pharm. 2018;10(2s);Suppl:S51-5. doi: 10.5530/jyp.2018.2s.10.

32. Ghanbarzadeh B, Babazadeh A, Hamishehkar H. Nanophytosome as a potential food-grade delivery system. Food Biosci. 2016;15:126-35. doi: 10.1016/j.fbio.2016.07.006.

33. Telange DR, Patil AT, Pethe AM, Fegade H, Anand S, Dave VS. Formulation and characterization of an apigenin-phospholipid phytosome (APLC) for improved solubility, in vivo bioavailability, and antioxidant potential. Eur J Pharm Sci. 2017;108:36-49. doi: 10.1016/j.ejps.2016.12.009. PMID 27939619.

34. Malvern Instruments. Zetasizer nano series user manual. Worcestershire, UK. Malvern; 2013.

35. Freag MS, Saleh WM, Abdallah OY. Self-assembled phospholipid-based phytosomal nanocarriers as promising platforms for improving oral bioavailability of the anticancer celastrol. Int J Pharm. 2018;535(1-2):18-26. doi: 10.1016/j.ijpharm.2017.10.053, PMID 29102699. ijpharm.2017.10.053.

36. Vlaardingerbroek H, van den Akker CHP, de Groof F, HogewindSchoonenboom JEH, Huang L, Riedijk MA, van der Schoor SRD, Huang Y, van Goudoever JB. Amino acids for the neonate: search for the ideal dietary composition. NeoReviews. 2011;12(9):e506-16. doi: 10.1542/neo.12-9-e506.

37. Sasongko RE, Surini S, Saputri FC. Formulation and characterization of bitter melon extract (Momordica charantia) loaded phytosomes. Pharmacogn J. 2019;11(6):1235-41. doi: 10.5530/pj.2019.11.192.

38. Gnananath K, Sri Nataraj K, Ganga Rao B. Phospholipid complex technique for superior bioavailability of phytoconstituents. Adv Pharm Bull. 2017;7(1):35-42. doi: 10.15171/apb.2017.005, PMID 28507935. 